22 Treem WR, Hyams JS, Blankschen E, Etienne N, Paule CL, Borschel MW Evaluation of the effect of a fiber-enriched formula on infantile colic. $J$ Pediatr 1991;119:695-701.

23 Weizman Z, Alkrinawi S, Goldfarb D, Bitran C. Efficacy of herbal tea preparation in infantile colic.J Pediatr 1993;122:650-2.

24 Illingworth RS. Evening colic in infants. A double-blind trial on dicyclomine hydrochloride. Lancet 1959;2:1119-20.

25 Grunseit F. Evaluation of the efficacy of dicyclomine hydrochloride ("Merbentyl") syrup in the treatment of infantile colic. Curr Med Res Opin 1977;5:258-61

26 Blomquist HK, Mjörndal T, Tiger G. Dicykloverinkloridlösning - hjälp vid svår spädbarnskolik. Läkartidningen 1983;80:116-8.

27 Weissbluth M, Christoffel KK, Davis AT. Treatment of infantile colic with dicyclomine hydrochloride. J Pediatr 1984;104:951-5.

28 Hwang CP, Danielsson B. Dicyclomine hydrochloride in infantile colic. BMJ 1985;291:1014.

29 Danielsson B, Hwang CP. Treatment of infantile colic with surface active substance (simethicone). Acta Paediatr Scand 1985;74:446-50.

30 Sehti KS, Sehti JK. Simethicone in the management of infantile colic Practitioner 1988;232:508.

31 Metcalf TJ, Irons TG, Sher LD, Young PC. Simethicone in the treatment of infantile colic: a randomized, placebo-controlled, multicenter trial. Pediatrics 1994:94:29-34.

32 Illingworth RS. Three months' colic. Treatment by methylscopolamine nitrate ("Skopyl"). Acta Paediatr 1955;44:203-8.

33 O'Donovan JC, Bradstock AS. The failure of conventional drug therapy in the management of infantile colic. Am J Dis Child 1979;133:999-100

34 Barr RG, McMullan SJ, Spiess H, Leduc DG, Yaremko J, Barfield R, et al Carrying as colic "therapy": a randomized controlled trial. Pediatric. 1991:87:623-30.

35 McKenzie S. Troublesome crying in infants: effect of advice to reduce stimulation. Arch Dis Child 1991;66:1416-20.

36 Parkin PC, Schwartz CJ, Manuel BA. Randomized controlled trial of three interventions in the management of persistent crying of infancy. Pediatrics 1993;92:197-201.

37 Wolke D, Gray P, Meyer R. Excessive infant crying: a controlled study of mothers helping mothers. Pediatrics 1994;94:322-32.

38 Westphal $\mathrm{O}$, Medin S. Behandling av 3-månaderskolik med yaktiv substans. Läkartidningen 1972;69:3331-4.

39 Taubman B. Parental counseling compared with elimination of cow's milk or soy milk protein for the treatment of infant colic syndrome: a randomized trial. Pediatrics 1988;81:756-61.

40 Oggero R, Garbo G, Savino F, Mostert M. Dietary modifications versus dicyclomine hydrochloride treatment of severe infantile colics. Acta Paediatr 1994;83:222-5.
41 Weizman Z, Alkrinawi S, Goldfarb D, Bitran C. Herbal teas for infantile colic. J Pediatr 1993;123:670-1.

42 Wolke D.The treatment of problem crying behavior. In: St James-Roberts I, Harris G, Messer D, eds. Infant crying, feeding and sleeping. New York: Harvester Wheatsheaf, 1993:47-79.

43 American Academy of Pediatrics, Committee on Nutrition. Soy protein formulas: recommendations for use in infant feeding. Pediatric 1983;72:359-63.

44 Businco L, Bruno G, Giampietro PG, Cantani A. Allergenicity and nutritional adequacy of soy protein formulas. J Pediatr 1992;121:S21-8.

45 Jakobsson I, Lindberg T. Cow's milk proteins cause infantile colic in breast-fed infants: a double-blind crossover study. Pediatrics 1983;71: 268-71.

46 Lothe L, Lindberg T. Cow's milk whey protein elicits symptoms of infantile colic in colicky formula-fed infants: a double-blind crossover study. Pediatrics 1989·83:262-6.

47 Williams J, Watkin-Jones R. Dicyclomine: worrying symptoms associated with its use in some small babies. BMJ 1984;288:901.

48 Carey WB. The effectiveness of parental counseling in managing colic Pediatrics 1994;94:333-4.

49 Forsyth BWC, Canny PF. Perception of vulnerability $31 \frac{1}{2}$ years after problems of feeding and crying behavior in early infancy. Pediatrics 1991;88:757-63.

50 Rautava P, Lehtonen L, Helenius H, Silanpää M. Infantile colic: child and family three years later. Pediatrics 1995;96:43-7.

51 Van den Boom DC. The influence of temperament and mothering on attachment and exploration: an experimental manipulation of sensitive responsiveness among lower-class mothers with irritable infants. Child Dev 1994;65:1457-77

52 Van den Boom DC. Do first-year intervention effects endure? Follow-up during toddlerhood of a sample of Dutch irritable infants. Child Dev 1995;66:1798-816.

53 Easterbrook PJ, Berlin JA, Gopalan R, Matthews DR. Publication bias in clinical research. Lancet 1991;337:867-72.

54 Moher D, Olkin I. Meta-analysis of randomized controlled trials. A concern for standards. JAMA 1995;274:1962-4.

55 Iacono G, Carroccio A, Montalto G, Cavataio F, Bragion E, Lorello D, et al. Severe infantile colic and food intolerance: a long-term prospective study. J Pediatr Gastroenterol Nutr 1991;12:332-5.

56 Pocock SJ. Clinical trials. A practical approach. Chichester: Wiley, 1988:111.

(Accepted 2 February 1998)

\title{
Immunological response to conjugate vaccines in infants: follow up study
}

\author{
D Goldblatt, E Miller, N McCloskey, K Cartwright
}

Immunising infants against Haemophilus influenzae type $\mathrm{b}$ with conjugate vaccines has reduced rates of invasive disease in the developed world. Reports from the Gambia suggest that this vaccine has a similar potential for the developing world. ${ }^{1}$ The World Health Organisation is considering whether to provide these new vaccines as part of its expanded programme of immunisation. $^{2}$

A booster dose of the conjugate vaccine administered in the second year of life is generally considered necessary to induce long term immunity against $H$ influenzae type b. This may limit the use of these conjugate vaccines in the developing world where vaccines are administered at 6,10 , and 14 weeks of age under the WHO's immunisation programme; delivery of further vaccinations are associated with logistical problems. In the United Kingdom, infant immunisation takes place in an accelerated fashion at 8, 12, and 16 weeks of age and no booster dose of the conjugate vaccine is administered. Evidence of the effectiveness of this schedule has been published, ${ }^{3}$ but its success in the United Kingdom may be related to the immunisation of all children younger than 5 years of age; this mass immunisation may have abruptly reduced nasopharyngeal carriage and modes of transmission.
To evaluate the effectiveness of the accelerated immunisation schedule in the United Kingdom we investigated whether the schedule primed infants' immune systems for memory responses at the age of 1 year.

\section{Subjects, methods, and results}

This study is a follow up of a previously reported study of the interchangeability of two conjugate vaccines against $H$ influenzae type $b .{ }^{4}$ Infants whose immune systems had been primed with a conjugate vaccine administered with diphtheria, tetanus, and pertussis vaccines at 2, 3, and 4 months of age received one of two conjugates, either ActHIB (Pasteur-Mérieux-MSD, Lyon) or HibTITER (Cyanamid-Lederle-Praxis Biologicals, Pearl River, USA) at the age of 1 year. $H$ influenzae type b polysaccharide (polyribosylribitolphosphate) IgG titres were estimated by enzyme linked immunosorbent assay after primary immunisation, and then immediately before and 1 month after the booster dose was administered.

Altogether 516 infants were recruited. Serum samples were obtained from 401 infants before they received a booster dose and 387 infants after they
Immunobiology Unit, Institute of Child Health, London WC1N 1EH D Goldblatt, senior lecturer N McCloskey, research fellow Immunisation Division, Public Health Laboratory Service, Communicable Disease Surveillance Centre, London NW9 5EQ E Miller,

head

continued over

BMJ 1998;316:1569-70 
Public Health

Laboratory,

Gloucester Royal

Hospital,

Gloucester

GL1 3NN

K Cartwright

group director

Correspondence to:

Dr Goldblatt

d.goldblatt@

ich.ucl.ac.uk received a booster dose. H influenzae type b polysaccharide IgG responses are shown in the table. The proportions of children who had antibody titres below the minimum protective level of $0.15 \mu \mathrm{g} / \mathrm{ml}$ before receiving their booster dose at 1 year of age was higher than previously reported with the more extended primary immunisation schedule. ${ }^{5}$ The mean increase in antibody titre after administration of the booster dose was 803 -fold (95\% confidence interval 651 to 955$)$.

\section{Comment}

This increase in antibody titres after booster immunisation is consistent with an immunological memory response, and shows that the children's immune systems were successfully primed by the three doses of conjugate vaccine they received during infancy. Immunological memory induced by vaccines administered

Geometric mean titre (95\% confidence interval) of Haemophilus influenzae type b polysaccharide $\operatorname{lgG}$, and the number (percentage) of infants with antibody titres below the minimum protective concentration $(0.15 \mu \mathrm{g} / \mathrm{ml})$ or above the long term protective concentration $(1.0 \mu \mathrm{g} / \mathrm{ml})$ after primary immunisation with three doses of conjugate vaccine, and immediately before and 1 month after a booster dose of the vaccine given at 1 year of age

\begin{tabular}{|c|c|c|c|c|}
\hline & \multirow[b]{2}{*}{ No } & \multirow[b]{2}{*}{ Geometric mean titre } & \multicolumn{2}{|c|}{ Antibody titre } \\
\hline & & & $<0.15 \mu \mathrm{g} / \mathrm{ml}$ & $>1.0 \mu \mathrm{g} / \mathrm{ml}$ \\
\hline After primary immunisation & 516 & 6.23 (5.53 to 7.01$)$ & $10(2)$ & $478(93)$ \\
\hline Immediately before booster dose & 401 & $0.41(0.35$ to 0.47$)$ & $153(38)$ & $126(31)$ \\
\hline 1 month after booster dose & 387 & 108.39 (91.62 to 128.23$)$ & $7(2)$ & $380(98)$ \\
\hline
\end{tabular}

according to the accelerated primary schedule may provide long term protection even when circulating antibody titres are low. Conjugate vaccines against $H$ influenzae type $\mathrm{b}$ could be introduced into the expanded immunisation programme of the WHO using a schedule of three doses in infancy and no booster dose. This should enhance deliverability and reduce costs.

Contributors: DG and EM designed the study. KC and EM coordinated the recruitment of patients and their follow up. DG and NM were responsible for developing the laboratory assay. The paper was written by all the authors. DG is guarantor for the study.

Funding: Medical Research Council. DG is a Welcome Trust Fellow.

Conflict of interest: None.

1 Mulholland K, Hilton S, Adegbola R, Usens S, Oparaugo A, Omosigho C, et al. Randomised trial of Haemophilus influenzae type-b tetanus protein conjugate for prevention of pneumonia and meningitis in Gambian infants. Lancet 1997:349:1191-7.

2 Steinhoff MC. Haemophilus influenzae type-b infections are preventable everywhere. Lancet 1997;349:1186-7.

3 Booy R, Heath PT, Slack MPE, Begg N, Moxon ER. Vaccine failures after primary immunisation with Haemophilus influenzae type-b conjugate vaccine without booster. Lancet 1997;349:1197-1202

4 Goldblatt D, Fairley CK, Cartwright K, Miller E. Interchangeability of conjugated Haemophilus influenzae type $\mathrm{b}$ vaccines during primary immunisation of infants. BMJ 1996;312:817-8.

5 Decker MD, Edwards KM, Bradley R, Palmer P. Responses of children to booster immunization with their primary conjugate Haemophilus influenzae type B vaccine or with polyribosylribitol phosphate conjugated with diphtheria toxoid. J Pediatr 1993;122:410-3

(Accepted 16 December 1997)
Public Health Directorate, Bro Taf Health Authority, Temple of Peace and Health, Cardiff CF1 3NW

Maria Z Morgan, research officer

Meirion R Evans, consultant in communicable disease control

Correspondence to: Dr Evans mre@abton4. demon.co.uk

BMJ 1998;316:1570-1

\title{
Initiatives to improve childhood immunisation uptake: a randomised controlled trial
}

\author{
Maria Z Morgan, Meirion R Evans
}

Levels of childhood immunisation are high in the United Kingdom but are proving difficult to maintain. Several initiatives to improve uptake have been described, including sending written information to parents, ${ }^{1}$ specialist immunisation clinics, ${ }^{2}$ and prompts to health visitors and general practitioners. ${ }^{3}$ However, none of these interventions has been the subject of a randomised controlled trial. We tested the effectiveness of two such interventions.

\section{Subjects, methods, and results}

The child health system, which maintains computerised data on immunisation status of all children, was used as the sampling frame. The study population comprised children resident in the former county of South Glamorgan who were (a) born between 1 April and 30 September 1995 and scheduled to complete the primary course of diphtheria, pertussis, tetanus, polio, and Haemophilus influenzae type b immunisation or $(b)$ born between 1 April and 30 September 1994 and scheduled to receive measles, mumps, and rubella immunisation. Children were included in the trial if they had not completed their primary course by
9 months of age or their measles, mumps, and rubella immunisation by 21 months of age.

Each week between 1 January and 30 June 1996 we received a computer generated list of children eligible for inclusion in the study and randomised each child using computer generated random numbers to one of two interventions or a control group. Intervention A comprised a non-directive telephone call to the child's health visitor to confirm the child's personal details and immunisation status. The health visitor was not informed of the trial and, although follow up of the child was anticipated, it was not specifically requested. Intervention B comprised a single mailed reminder to the child's parents together with a questionnaire about details of immunisation status and reasons for non-immunisation, and a reply paid envelope. Parents were not informed of the trial.

Study end points were completion of $(a)$ primary immunisation by the first birthday or $(b)$ measles, mumps, and rubella immunisation by the second birthday. We performed statistical analysis on an intention to treat basis, using the $\chi^{2}$ test with Yates's correction for baseline comparisons, and calculated 95\% confidence intervals for the difference in proportions. 